Research Papers, part of a Special Feature on Conservation of Grassland Birds: Causes and Consequences of Population Declines

\title{
Effects of Disturbance Associated with Natural Gas Extraction on the Occurrence of Three Grassland Songbirds
}

\section{Effet du dérangement associé à l'extraction de gaz naturel sur l'occurrence de trois oiseaux de prairie}

\author{
$\underline{\text { Laura E. Hamilton }}^{1}, \underline{\text { Brenda C. Dale }}^{2}$, and Cynthia A. Paszkowski $^{1}$
}

\begin{abstract}
Despite declines in the grassland bird guild and increasing rates of natural gas extraction on the Canadian prairies, relatively few studies have examined the effects of well sites and related infrastructure on these species. We conducted point counts on Canadian Forces Base Suffield, Alberta to investigate the effects of two well densities (high: 16 wells $/ 2.59 \mathrm{~km}^{2}$, low: 9 wells $/ 2.59 \mathrm{~km}^{2}$ ) on Savannah Sparrow (Passerculus sandwichensis), Chestnut-collared Longspur (Calcarius ornatus), and Sprague's Pipit (Anthus spragueii) occurrence and abundance. Additionally, model building was employed to determine if landscape features, i.e., soil type, elevation, and topography, along with well density and anthropogenic disturbance to natural vegetation, i.e., the combined areas affected by wells, pipelines, trails, and roads, could predict the occurrence of the three species. For Savannah Sparrows, occurrence and abundance were higher in areas with high well densities compared with low well densities, reflecting the species' general tolerance of human disturbances. Chestnut-collared Longspurs were ubiquitous in the study area and abundance was not related to well density. Models for this species performed poorly and failed to predict occurrence accurately. Models for Sprague's Pipit were the strongest and showed that this species' occurrence was negatively related to anthropogenic disturbance. For all three species, landscape features had low predictive power. Our results indicate that disturbance caused by well sites and related infrastructure affect occurrence of some species and should be incorporated into conservation strategies for grassland birds, especially as undisturbed grasslands become candidates for energy development.
\end{abstract}

RÉSUMÉ. Malgré le déclin des espèces de la guilde des oiseaux de prairie et le taux accru d'extraction de gaz naturel dans les Prairies canadiennes, relativement peu d'études ont examiné l'effet des sites de puits et d'infrastructures connexes sur ces espèces. Nous avons effectué des dénombrements par points d'écoute sur la base des forces canadiennes Suffield, en Alberta, afin d'étudier l'effet de deux densités de puits (élevée : 16 puits $/ 2,59 \mathrm{~km}^{2}$; faible : 9 puits $/ 2,59 \mathrm{~km}^{2}$ ) sur l'occurrence et l'abondance du Bruant des prés (Passerculus sandwichensis), du Plectrophane à ventre noir (Calcarius ornatus) et du Pipit de Sprague (Anthus spragueii). Nous avons également construit des modèles afin de déterminer si les caractéristiques du paysage (type de sol, altitude et topographie), de même que la densité des puits et les modifications anthropiques occasionnées à la végétation naturelle (l'ensemble des endroits touchés par les puits, pipelines, chemins et routes), permettaient de prévoir l'occurrence de ces trois espèces. Chez le Bruant des prés, l'occurrence et l'abondance étaient supérieures aux endroits où la densité de puits était élevée, conformément à la tolérance au dérangement humain observée chez cette espèce, en général. L'abondance du Plectrophane à ventre noir, espèce ubiquiste dans notre aire d'étude, n'était pas liée à la densité de puits.

\footnotetext{
${ }^{1}$ Department of Biology, University of Alberta, ${ }^{2}$ Canadian Wildlife Service,
} Environment Canada

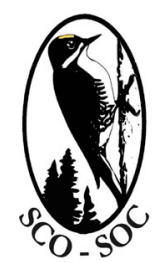

Sponsored by the Society of Canadian Ornithologists and Bird Studies Canada

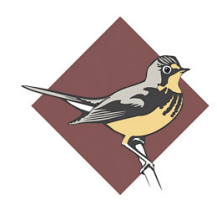


Les modèles pour cette espèce ne donnaient pas de bons résultats et n'ont pas su prévoir l'occurrence avec exactitude. Quant aux modèles pour le Pipit de Sprague, ils se sont avérés les plus puissants d'entre tous et ont montré que l'occurrence de cette espèce était négativement reliée aux dérangements anthropiques. Chez l'ensemble des trois espèces, les caractéristiques du paysage n'étaient pas de bonnes variables pour prévoir leur occurrence et leur abondance. Nos résultats indiquent que le dérangement attribué aux sites de puits et aux infrastructures connexes affecte l'occurrence des certaines espèces et devrait être pris en considération dans les stratégies de conservation d'oiseaux de prairie, particulièrement si des prairies vierges se retrouvent dans la mire du développement énergétique.

Key Words: anthropogenic disturbance; Chestnut-collared Longspur; grassland; modeling; natural gas; Savannah Sparrow; Sprague’s Pipit

\section{INTRODUCTION}

Recent population declines of grassland birds have been linked to direct habitat loss and habitat degradation (as reviewed by Samson et al. 2004, Brennan and Kuvlesky 2005, Askins et al. 2007). Previous research has identified a variety of sources of habitat degradation. Of these, the effects of activities of the energy sector have only received modest attention, despite the growing number of areas affected (Askins et al. 2007, Dale et al. 2009). Discoveries of natural gas and oil beneath the Canadian prairies has spurred the creation of a complex network of pipelines and well sites; today, oil and gas developments are found throughout the short and mixed-grass prairies in Canada (Askins et al. 2007). Our objective was to determine if natural gas development alone, or in combination with natural habitat features, affects the occurrence of three representative grassland birds, using Canadian Forces Base (CFB) Suffield in southeast Alberta as a study system.

A number of activities, and thus potential types of disturbance, are associated with natural gas extraction including digging trenches for the installation of pipelines and junctions, creation of and travel on access trails, i.e., unmaintained twotrack vehicle trails used to visit wells, and larger roads, and the creation and maintenance of well sites. The majority of research on potential types of disturbance in grassland habitat has focused on the effects of trails and roads rather than pipelines or well sites. Off-road access trails are assumed to have lower impacts than gravel or paved roads because of less extensive spatial changes to vegetation structure (Sutter et al. 2000), but even narrow trails are not without effects on avian abundance and productivity (Miller et al. 1998, Barton and Holmes 2007). Habitat degradation occurs along road and trail edges where vegetation often differs in species composition and structure from native prairie (Sutter et al. 2000, Koper and Schmiegelow 2006, but see Ingelfinger and Anderson 2004). In addition to this, traffic noise can decrease abundance and breeding activity near roads (Reijen et al. 1996, Forman et al. 2002, Ingelfinger and Anderson 2004). Soil disturbance caused by traffic along offroad trails can lead to invasion by non-native plant species (Trombulak and Frissell 2000, Larson et al. 2001, von der Lippe and Kowarik 2007; B. Smith, unpublished manuscript). Effects of other infrastructure accompanying oil and gas development, such as pipelines, on grassland wildlife and habitat in Canada have not been well studied, especially not in the context of diverse co-occurring disturbances (Askins et al. 2007).

Habitat modeling has proven to be a useful tool to determine how human developments, interacting with natural features, affect the occurrence of grassland birds (e.g., Davis 2004, Koper and Schmiegelow 2006, Winter et al. 2006). Studies of the roles of local habitat and landscape features in determining patterns of occurrence of grassland species have typically used on-the-ground measurements such as vegetation height, cover by standing dead vegetation, and bare ground to establish associations (e.g., Wiens 1969, Dale 1983, Davis 2004, Koper and Schmiegelow 2006). However, dependence on methods that require substantial investments in time and resources may 
preclude collection of large, robust sample sizes, especially in locations where the breeding season is short or access is limited. An intensive approach helps explain local patterns for bird assemblages, but resulting predictions regarding occurrence and abundance of species cannot be extrapolated, even within a study area, if detailed information on vegetation is unavailable.

In our study, we focused on the effects of larger scale habitat features and broad soil type categories to create models. Indirect measures of landscape features offer an attractive alternative for model building that might yield accurate predictors of occurrence. Where larger scale landscape features have been included in studies of grassland birds, these features have typically characterized the landscape habitat matrix, patch size, and distance to edge or disturbed habitat (for examples see Winter et al. 2000, Davis 2004, Koper and Schmiegelow 2006) rather than the indirect measures of physiognomy such as employed by Renfrew and Ribic (2002), Wiens et al. (2008), and which we adopted as well. Inclusion of additive estimates of the areal extent of alteration of native vegetation by industrial activities in models may add to their predictive power and realism if grassland birds respond to a suite of multiple, interconnected sources of disturbance rather than responding independently to single sources. Additionally, disturbance may be amplified or mitigated by the responses of local vegetation to topography and soil type. For example, the response of vegetation to soil compaction associated with roads and trails can be affected by the local soil type (Dickson et al. 2008).

To assess the effects of natural gas development on the occurrence of grassland birds, we focused on three species that were common on CFB Suffield: Savannah Sparrow (Passerculus sandwichensis), Chestnut-collared Longspur (Calcarius ornatus), and Sprague's Pipit (Anthus spragueii). These species differ in their tolerance of human disturbance and associated vegetation patterns, thus human disturbance at CFB Suffield was expected to shape fundamental habitat selection. We expected that Savannah Sparrow occurrence and abundance would be positively related to increased human disturbance because the species is attracted to landscape features such as roads (Sutter et al. 2000). Chestnut-collared Longspurs are less tolerant of roads than trails (Sutter et al. 2000) and are also less common in small patches of grassland (Davis 2004), thus its occurrence and abundance were expected to show modest declines in response to human disturbance. Finally, Sprague's Pipit was expected to occur less frequently and in lower numbers in areas with high levels of disturbance. Pipits are less likely to use non-native habitat (Robbins and Dale 1999, McMaster and Davis 2001); occurrence and abundance are positively related to the size of patches of native vegetation and negatively related to the amount of edge (Davis 2004, Davis et al. 2006). Previous research on CFB Suffield found pipits to be less common in areas with higher well densities (Dale et al. 2009). We employed habitat modeling using large-scale natural features and anthropogenic disturbance associated with natural gas development to determine which set of factors described the occurrence of these three species of grassland birds most successfully.

\section{METHODS}

\section{Study site}

The study was conducted in 2007 and 2008 on the south block of CFB Suffield, in southern Alberta, approximately $50 \mathrm{~km}$ northwest of Medicine Hat and $250 \mathrm{~km}$ southeast of Calgary $\left(50^{\circ} 14^{\prime} \mathrm{N}, 110^{\circ}\right.$ $37^{\prime} \mathrm{W}$ ). This site was chosen because of the presence of the $458 \mathrm{~km}^{2}$ National Wildlife Area (NWA) and a recent proposal to increase the density of wells in the area (CEAR 2007). At present, on the majority of the base and in the NWA, the average density of natural gas wells does not exceed 16 wells per 2.59 $\mathrm{km}^{2}$. The NWA has not been used for military ground training since 1972 and has light to moderate cattle grazing (CEAR 2007).

Using ArcGIS (9.2), eight $3-\mathrm{km}^{2}$ plots of native mixed-grass prairie were selected within the NWA and an adjacent pasture on the base which is also not used for ground training (Fig. 1). Each plot was designated as experiencing low $(\mathrm{n}=5)$ or high $(\mathrm{n}=$ 3) impact based on the density of natural gas wells as determined by Canadian Wildlife Service from purchased well location data and data on trails provided by the Department of National Defense. Low well density sites had an average of almost 9 wells $/ 2.59 \mathrm{~km}^{2}$ whereas high well density sites had an average of approximately 15 wells $/ 2.59 \mathrm{~km}^{2}$ 
Fig. 1. Map of the study area in 2007 and 2008 on Canadian Forces Base Suffield in Alberta, Canada. Squares indicate $9 \mathrm{~km}^{2}$ plots in both years; dots indicate location of point counts. Solid squares indicate low well density areas whereas dashed squares represent high well density areas.
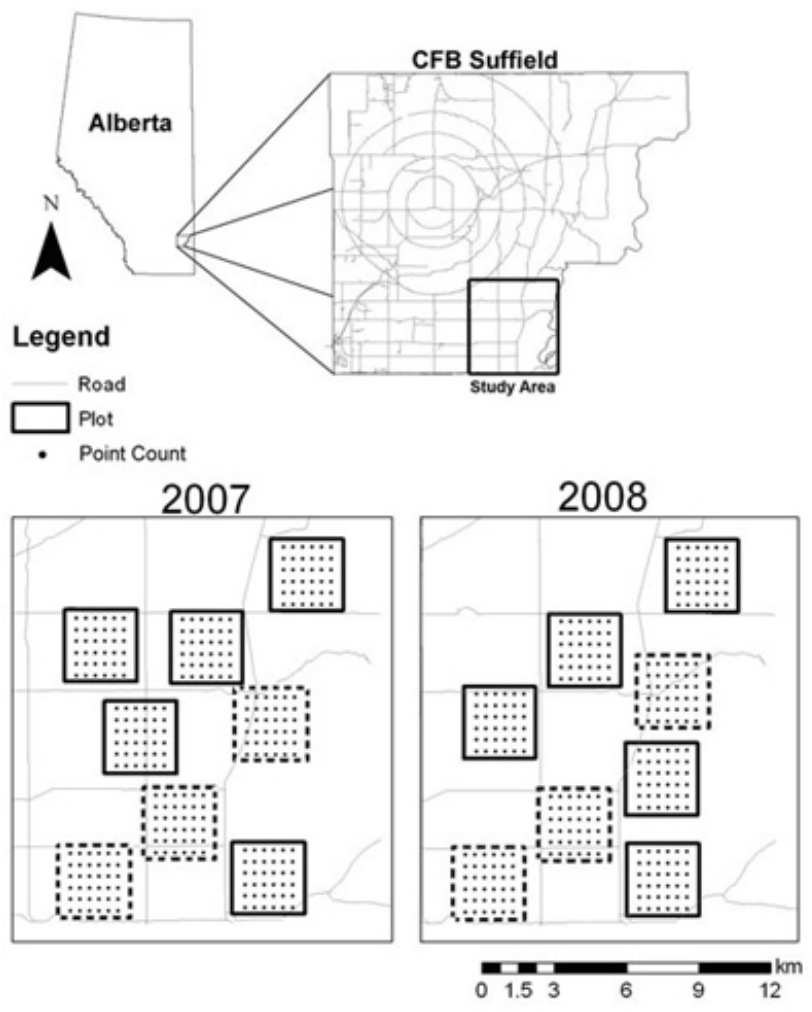

(Table 1). In 2007, wildfires occurred on some of the study points prior to sampling. Because of these fires, some plots were moved in 2008 to avoid burned areas producing a total of 10 plots. We used ecological range site classification (Adams et al. 2004) and previous bird surveys (B. C. Dale, P. S. Taylor, and J. P. Goossen, unpublished manuscript) to determine the soil types most frequently associated with our focal species and situated our plots on predominantly loam and sandy sites. We attempted to situate plots in a manner that equalized the proportion of the two soil types between sites supporting the two well densities.

Point counts were conducted from 15 to 26 May 2007 and 9 May to 5 June 2008 to document the distribution and relative abundances of the three target species on each of the eight study plots. The extended period for point counts in 2008 was required because large portions of the study area were closed because of military training; heavy rainfall also interfered with sampling. Point counts were conducted in a grid of six points by six points, yielding 36 point counts per plot. The grid of point counts was $250 \mathrm{~m}$ from the edge of the plot and each series of points was $500 \mathrm{~m}$ apart. Each 36-point plot was divided between two observers. Observer "L" conducted counts in both 2007 and 2008; the other two observers ("A" and "S") were present during one field season each. Training of observers occurred prior to the beginning of data collection and concentrated on distance estimation, bird identification, behavior, and the recording protocol. Counts began as close to sunrise as possible ( 0530), and ended no later than 1100. During each five-minute count, start and end time was recorded 
Table 1. A priori models for generalized linear modeling of occurrence of three grassland bird species using binomial log-link functions. See text for further description of parameters.

\begin{tabular}{ll}
\hline \hline Model name & Model parameters \\
\hline Global model & $\begin{array}{l}\text { Year + Observer + Date + Elevation + Topographic Index + Soil Particle Size + Well Density } \\
\text { + Disturbance to Vegetation }\end{array}$ \\
Habitat without soil & Observer + Date + Elevation + Topographic Index \\
Habitat & Observer + Date + Elevation + Topographic Index + Soil Particle Size \\
Cumulative disturbances & Observer + Date + Well Density + Disturbance to Vegetation (trails, pipelines, well pads) \\
Well density & Observer + Date + Well Density \\
Disturbance to vegetation & Observer + Date + Disturbance to Vegetation \\
\hline
\end{tabular}

as well as wind speed based on the Beaufort Scale. Counts were halted if wind reached Beaufort class $4(\sim 20 \mathrm{~km} / \mathrm{hr})$. Each point was a circle with a 100 $\mathrm{m}$ radius and a bird was recorded when seen, heard singing or calling, observed moving, or involved in a chase. A bird's sex was recorded when possible. Immediately upon return from the field, observers estimated the number of breeding pairs within each point count station based on the behavior observed.

\section{Analysis}

\section{Statistical approach}

Wildfires occurred in the study area prior to 15 May 2007, and prior to 9 May 2008. Point count stations that had a burned area within $250 \mathrm{~m}$ were removed from the data set prior to any analysis because recently burned areas were generally uninhabited by the study species. We analyzed results from 267 point counts in 2007 and 277 point counts in 2008 for a total of 544 point counts. Years were pooled based on similar abundances and trends in bird abundance and occurrence in both years (see Hamilton 2010). Point counts were clustered based on the plot in which they occurred resulting in a sample size of 10 .

To determine if well density, a measure used by industry that is an indicator of overall disturbance associated with the level of energy development, was an effective predictor of abundance of breeding pairs within the $100 \mathrm{~m}$ radius point counts, analyses were carried out using SPSS 16.0 for Windows (SPSS Inc. Chicago, IL USA) and R (version 2.11.1) using data generated from point counts in 2007 and 2008. All values are presented as mean \pm standard error unless otherwise noted. Study species were analyzed separately throughout. Mann-Whitney U tests compared the effect of well density on the estimated number of birds per point count for each species. Post-hoc power tests were performed using $\mathrm{R}$ (version 2.11.1) to determine minimal effect size (MES) for analyses that failed to detect a significant difference.

Bird occurrence was modeled using generalized linear mixed model (GLMM) regressions based on a binomial logit-link function $(\mathrm{R}$ version 2.11.1; glmmML written by Göran Broström, Umeå University, Sweden) to compare a series of a priori habitat models created to assess the relationship between disturbance associated with natural gas extraction and underlying natural habitat characteristics on the presence/absence of the study species on a landscape scale. This glmmML package was selected because it fits models using maximum likelihood, thus allowing use of information theoretic approaches for model selection. Additionally, glmm allows the use of a clustering variable, in this case Site ID, to account 
for replication of sites between years. Two categorical variables were included, observer (A, L, or S) in which observer L, who was present in both sampling seasons, served as the reference category. Year was the second categorical variable with 2007 serving as the reference category.

\section{Explanatory variables}

We used three variables to characterize natural habitat within the $100 \mathrm{~m}$ radius surrounding point count localities: elevation, topographic index, and soil particle size. Elevation was the mean value obtained within $100 \mathrm{~m}$ of the center of the point count from a digital elevation map of the area using the Digital Elevation Model (DEM) from GeoBase (Natural Resources Canada 2004). The topographic index, following Wiens et al. (2008), was a measure of the flatness of an area. It was derived by dividing the actual surface area of the DEM within a survey site by the area encompassed by a point count if the land had been perfectly flat. Thus a site that was flat had a value of 1; hollows and hillier areas received higher topographic index values. Soil particle size, following Wiens et al. (2008), was generated from soil-texture information provided by Alberta Soil Information Center (2001). A weighted mean of the soil textures in each horizon within the point circle was calculated. Soil texture designations were ranked from 1 to 13 with increasing value indicating a coarser soil. Therefore, an increase in the index corresponded to an increase in particle size with larger particles reflecting soils that, in the case of CFB Suffield, contained more sand. Date of individual point counts was included in models to account for timing of surveys, especially in 2008, when counts were spread over nearly one month. Data were centered to improve the interpretation of variables as per Schielzeth (2010).

Human disturbance was characterized by well density and total industrial disturbance within 100 $\mathrm{m}$. Well density was calculated by determining the number of well sites that occurred within a circle with a total area of $2.59 \mathrm{~km}^{2}$ (radius $=908 \mathrm{~m}$, or 1 square mile) centered on the point count. This variable was selected to determine if the overall density of wells at a larger spatial scale differed in its effect on species occurrences from very local anthropogenic disturbances immediately surrounding a point count. Because wells were not spaced evenly across the study sites, some locations within individual plots had higher local well densities than others. Thus this variable reflects the density of wells in relation to individual point counts. Well density within 1 square mile is used by industry and indicates the overall level of disturbance at a site as it reflects not just the number of wells, but the extent of linear features, such as pipelines and trails, associated with the creation and upkeep of well sites. Well density was also included because it proved important in earlier models of habitat use of Sprague's Pipit (Government of Canada 2008).

We calculated total human disturbance to vegetation within $100 \mathrm{~m}$ of a point count by assigning each potential disturbance, i.e., well site, pipeline, junction, trail, and road, a fixed area or width of influence, based on personal observation or environmental assessment reports for CFB Suffield's NWA (CEAR 2007), and then summing these values. For each linear disturbance the length of the disturbance within the point-count circle was multiplied by the standard width to calculate area of disturbance. Pipelines were assigned a standard width of $2.5 \mathrm{~m}$, whereas roads, including drainage ditches, were assigned a width of $25 \mathrm{~m}$. Trail width was based on the Department of National Defense classification of the disturbance of the trail (class $1-5)$ to determine the area directly impacted by the trail (Class $1=0.4 \mathrm{~m}$; Class $2=1.5 \mathrm{~m}$; Class $3=2$ $\mathrm{m}$; Class $4=3 \mathrm{~m}$; Class $5=4 \mathrm{~m}$ ). Class 1 trails were defined as cattle or wild ungulate trails, but we noted that some were actually remnants of class 2 trails. Because of our inability to determine if a class 1 trail was an infrequently used and partially revegetated vehicle trail, a cattle or wild ungulate trail, all trails were categorized as anthropogenic disturbance. Well sites were assigned a disturbance surface area of $860 \mathrm{~m}^{2}$ while pipe junctions were assigned a disturbance area of $400 \mathrm{~m}^{2}$ (CEAR 2007).

To determine if areas supporting high and low well densities differed in habitat features, all covariates, except for topographic index, were compared between high and low well density areas using ttests assuming unequal variance after testing for normality. The topographic index was compared between high and low well density areas using a Mann-Whitney U test. Mean, standard deviation, and range for covariates are provided in Table 1. 


\section{Model selection}

Site ID, a tag to distinguish individual point count locations, was included in all models as a random effect to account for replication at some locations between years. All other variables were included as fixed effects. Six models were constructed, based on a priori hypotheses. Models were designed to separate natural and human influences, in addition to evaluating the effect of landscape variables, on the pattern of occurrence of grassland birds (See Table 1 for a description of a priori models). The first was a global model (1) that included all variables. Two models focused upon the natural site characteristics, one without soil particle size (2) and one with particle size (3) to determine if soil particle size was a functional measure of bird habitat use or if topography and elevation alone could explain bird presence. Another model (4) contained all measures of anthropogenic disturbances linked to natural gas extraction. The final two models included well density within a square kilometer (5) and total disturbance to native vegetation owing to natural gas extraction (6).

When the odds ratio (OR) and the lower bound of the confidence interval (CI) were greater than 1 , there was a positive effect of a variable on the likelihood of a species' presence. When the odds ratio and the upper bound of the confidence interval were less than 1 , there was a negative effect on a variable on the likelihood of a species' presence (Burnham and Anderson 2002).

Akaike Information Criterion (AIC) was used to select the model of best fit from the suite of eight candidate models (Burnham and Anderson 2002). Models with a $\mathrm{D} i<2$ were considered equivalent, whereas models with $\mathrm{D} i=3-7$ had less support. Models with $D i>7$ had very little support compared to the best model (Burnham and Anderson 2002). Akaike weights $\left(\mathrm{w}_{i}\right)$ were used to determine the probability that the model with the lowest AIC was the best model. The closer $\mathrm{w}_{i}$ was to 1 , the more likely that the best model was the most useful model of those tested (Burnham and Anderson 2002).

The validity of the best and equivalent models, in other words the ability of each model to predict occurrence of one of the species within our study area, was determined by calculating the area under the receiver operator curve (AUC) which was averaged between five replications of the model following the approach of Venier et al. (2004). Model replication was performed by dividing the data randomly into five bins with each bin being withheld once for model replication and testing. Thus, each replication of the model used $80 \%$ of the data points and was tested against the remaining $20 \%$ points. The model that produced the largest area under the curve was maintained. We judged the predictive usefulness of the best model(s) using the criteria of Fielding and Bell (1997): an AUC of 0.5 indicated the model performed no better than random and, as AUC approached 1, predictive accuracy increased, with 0.70 being considered a reasonable cutoff for a valid model. In the present study, model averaging was employed for species models with high AUC values where there was no one best model with a low AIC or with a high model weight $\left(\mathrm{w}_{i}\right)$. Models were averaged by multiplying estimated coefficients by $\mathrm{w}_{i}$ and summing these parameters across all models (Burnham and Anderson 2002).

\section{RESULTS}

\section{Completed point counts}

Point counts in 2007 consisted of 108 from high well density areas and 159 from low well density areas. In 2008, 105 point counts were conducted in high well density areas and 172 from low well density areas. Observer L conducted 132 useable point counts in 2007 and 137 in 2008 . Observer S conducted 135 point counts in 2007 and Observer A conducted 140 in 2008.

\section{Environmental differences between high and low well density areas}

For all study points combined, an average of $2.9 \%$ of a surrounding circle $100 \mathrm{~m}$ in area was disturbed owing to natural gas extraction. Low well density point counts had an average of $2.5 \%$ area that had human disturbance whereas high well density point counts had an average of $3.4 \%$ disturbance. Trails accounted for the majority of disturbances followed by pipelines, well sites, and roads. Sites with high and low densities of wells had similar topography but differed significantly in elevation, soil particle size, and disturbance of native vegetation (Table 2 ). 
Table 2. Summary of values for environmental variables recorded in CFB Suffield for 360 low well density point count locations and 216 high well density point count locations for 2007 and 2008 combined. Points affected by fire $(\mathrm{n}=32)$ were excluded. * indicates significance $(\alpha<0.05)$ using a t-test assuming unequal variances.

\begin{tabular}{lccccc}
\hline \hline Parameter & \multicolumn{2}{c}{ Low } & & \multicolumn{2}{c}{ High } \\
\cline { 2 - 3 } \cline { 5 - 6 } & $1001.0 \pm 0.08$ & $1000-1014.2$ & & $1001.1 \pm 0.1$ & $1000-1008.1$ \\
\hline Topographic index & $112.5 \pm 0.7$ & $82-161$ & & $131.2 \pm 1.2$ & $90-166$ \\
Elevation (m)* & $2.5 \pm 0.2$ & $0-22.9$ & & $3.4 \pm 0.3$ & $0-21.9$ \\
Percentage of area with disturbance to & $11.2 \pm 0.2$ & $6.4-14.1$ & & $9.7 \pm 0.2$ & $6.4-14.1$ \\
vegetation (\%) * & $8.4 \pm 0.07$ & $5-15$ & & $15.3 \pm 0.2$ & $7-22$ \\
Soil particle Size (unitless)* & & & & \\
Well density (\#) * & & & & & \\
\hline
\end{tabular}

Sites with high well density were at higher elevations and had smaller soil particle sizes, although there was broad overlap in values for elevation and soil particle size between the two well densities.

\section{Distribution and abundance patterns of bird species}

Chestnut-collared Longspur was the most abundant of the study species with an average of 1.38 birds/ point in 2007 and 1.24 birds/point in 2008. This was followed by Savannah Sparrow (2007: 0.76/point and 2008: 0.67/point) with Sprague's Pipit being the least abundant species among the three studied (2007: 0.56/point and 2008: 0.62/point; Table 3).

Savannah Sparrows were significantly more abundant in high than in low well density areas ( $\mathrm{Z}$ $=-2.02, \mathrm{n}=544, \mathrm{p}=0.04)$. There was no significant effect of well density on abundance of Chestnutcollared Longspurs $(\mathrm{Z}=-1.57, \mathrm{n}=544, \mathrm{p}=0.12$, MES $=21.1 \%$; Table 3 ) or Sprague's Pipits $(Z$ $=-1.30, \mathrm{n}=544, \mathrm{p}=0.19, \mathrm{MES}=20.6 \%$; Table 3).

\section{Generalized linear mixed models}

Of all the models tested, only models predicting the occurrence of Sprague's Pipit consistently produced AUC values greater than 0.50 (Table 4). Of these pipit models, the best had an average AUC of 0.66 (range: $0.62-0.69, \mathrm{n}=5$ ), indicating that the model had some predictive power. For Sprague's Pipit, the three best models were the disturbance to native vegetation (model 6 above), disturbance to vegetation including well density (model 4 ), and the global model (1). The likelihood of occurrence of Sprague's Pipit was negatively associated with percentage of area with vegetation disturbed by natural gas extraction $(\mathrm{OR}=0.93, \mathrm{CI}=0.94-0.99$; Table 5, Fig. 2).

The best models for the other two species performed only slightly better than null models. The highest AUC produced for a Savannah Sparrow model was the model based on habitat features excluding soil texture (model 2; AUC $=0.55$; range: $0.50-0.61$, $\mathrm{n}=5)$. The best model for Chestnut-collared Longspur featured the disturbance to native vegetation within $100 \mathrm{~m}$ of point counts, but this model had very little predictive power (model 6; average AUC $=0.47$, range: $0.42-0.52, \mathrm{n}=5$ ). A summary of the best Savannah Sparrow and Chestnut-collared Longspur models are presented in Tables 6 and 7. 
Table 3. Mean abundance of three bird species for point counts conducted in areas of low and high well density on CFB Suffield in 2007 and 2008. Effect sizes represent the difference between well densities assuming that low well densities are the base state. $\dagger$ Effect size calculated as [(High - Low)/Low] $* 100$

\begin{tabular}{lccc}
\hline \hline & $\begin{array}{c}\text { Low } \\
(\mathrm{n}=341)\end{array}$ & $\begin{array}{c}\text { High } \\
(\mathrm{n}=213)\end{array}$ & $\begin{array}{c}\text { Effect Size } \\
(\%) \dagger\end{array}$ \\
\hline Savannah Sparrow & $0.67 \pm 0.046$ & $0.82 \pm 0.062$ & +22.4 \\
Chestnut-collared Longspur & $1.23 \pm 0.060$ & $1.44 \pm 0.088$ & +17.1 \\
Sprague's Pipit & $0.63 \pm 0.037$ & $0.54 \pm 0.043$ & -14.3 \\
\hline
\end{tabular}

Despite attempts to situate point count blocks equally on the two major soil types at the study site and to control for elevation, there were significant differences in soil structure and elevation between low and high well density areas. However, given that neither soil structure nor elevation were adequate descriptors of species presence, these differences were unlikely to have influenced our assessment of the occurrence of the study species relative to natural gas development.

\section{DISCUSSION}

\section{Response to extent of anthropogenic disturbance}

Well density had a positive effect on the abundance of Savannah Sparrows, no effect on Chestnutcollared Longspurs, and a negative effect on Sprague's Pipits. Savannah Sparrows displayed higher occurrence and abundance on areas with high well densities, which agreed with our prediction. Our best generalized linear mixed model showed a positive relationship between the extent of disturbance to vegetation caused by infrastructure and the occurrence of Savannah Sparrow. In an earlier study, Dale et al. found that an increase from 4 wells per $2.59 \mathrm{~km}^{2}$ (as present in 1994-1995) to the current density of 8 to 16 wells per $2.59 \mathrm{~km}^{2}$ on CFB Suffield was accompanied by an increase in abundance of Savannah Sparrows that ranged from $170 \%$ to more than $500 \%$ across survey sites (B. C. Dale, P. S. Taylor, and J. P. Goossen, unpublished manuscript). Positive associations between Savannah Sparrow and disturbance are not universal. On the tundra of the Northwest Territories, Canada, Savannah Sparrows occurred at similar abundances on seismic lines and along control transects (Ashenhurst and Hannon 2008).

Consistent with the lack of a significant effect of well density on abundance of Chestnut-collared Longspur, our best generalized linear mixed model for the occurrence of this species performed poorly, but did suggest a greater influence of natural habitat features than human-generated disturbance to vegetation. Hill and Gould (1997) noted that Chestnut-collared Longspurs tend to form aggregated clumps of breeding birds that often move outside their territories, which can inflate density estimates and blur core habitat preference. Therefore, longspur territorial behavior may have affected our ability to predict accurately habitat used by this species.

Sprague's Pipit was the only study species that tended to be less abundant in areas with high well density. The best pipit model indicated that the level of human disturbance had a significant negative effect on the species' occurrence whereas natural habitat variables had relatively less effect. These findings are all consistent with our predictions. Dale et al. (2009) reported a nonsignificant decline in pipit abundance over time with a coincidental increase in well density on CFB Suffield. 
Table 4. Generalized linear mixed model logistic regression analysis of hypothesized a priori models based on "K" variables to determine presence-absence of Savannah Sparrow (Passerculus sandwichensis), Chestnut-collared Longspur (Calcarius ornatus), and Sprague's Pipit (Anthus spragueii) on CFB Suffield from 544 point counts measured in 2007 and 2008. See Table 1 for model variables.

\begin{tabular}{|c|c|c|c|c|c|}
\hline Model & $\mathrm{K}$ & AIC & $\Delta_{i}$ & $\mathrm{w}_{i}$ & Mean AUC $(n=5)$ \\
\hline \multicolumn{6}{|l|}{ Savannah Sparrow } \\
\hline Global model & 10 & 731.3 & 0 & 0.97 & 0.53 \\
\hline Habitat & 6 & 735.6 & 4.3 & 0.09 & 0.55 \\
\hline Habitat without soil & 5 & 737.4 & 6.1 & 0.04 & 0.55 \\
\hline Cumulative disturbance & 5 & 737.7 & 6.4 & 0.03 & 0.51 \\
\hline Disturbance to Vegetation & 4 & 738.2 & 6.9 & 0.03 & 0.51 \\
\hline Well density & 4 & 744.2 & 12.9 & 0.001 & 0.54 \\
\hline \multicolumn{6}{|l|}{ Chestnut-collared Longspur } \\
\hline Habitat without soil & 5 & 574 & 0 & 0.46 & 0.41 \\
\hline Global model & 10 & 574.8 & 0.8 & 0.31 & 0.44 \\
\hline Habitat & 6 & 575.4 & 1.4 & 0.23 & 0.42 \\
\hline Cumulative disturbances & 5 & 607.2 & 33.2 & $<0.001$ & 0.44 \\
\hline Well density & 4 & 609.5 & 35.3 & $<0.001$ & 0.43 \\
\hline Disturbance to vegetation & 4 & 609.6 & 35.4 & $<0.001$ & 0.47 \\
\hline \multicolumn{6}{|l|}{ Sprague's Pipit } \\
\hline Disturbance to Vegetation & 4 & 743.9 & 0 & 0.49 & 0.65 \\
\hline Cumulative disturbances & 5 & 744.7 & 0.8 & 0.33 & 0.66 \\
\hline Global model & 10 & 746.8 & 2.9 & 0.11 & 0.59 \\
\hline Well density & 4 & 749.7 & 5.8 & 0.03 & 0.64 \\
\hline Habitat & 6 & 749.8 & 5.9 & 0.03 & 0.66 \\
\hline Habitat without soil & 5 & 751 & 7.1 & 0.01 & 0.64 \\
\hline
\end{tabular}


Table 5. Summary of the mixed model logistic regression for describing the model averaged presenceabsence of Sprague's Pipit (Anthus spragueii) on 544 points on CFB Suffield from 2007 and 2008 using a $100 \mathrm{~m}$ radius surrounding a point count location using treatment contrasts. Bolded parameters indicate odds ratios that differ from one.

\begin{tabular}{|c|c|c|c|c|c|}
\hline \multirow{2}{*}{$\frac{\text { Parameter }}{\text { Intercept }}$} & \multirow{2}{*}{$\begin{array}{c}\text { Coefficient } \\
-11.54\end{array}$} & \multirow{2}{*}{$\begin{array}{c}\text { Standard Error } \\
8.33\end{array}$} & \multirow[t]{2}{*}{ Odds Ratio } & \multicolumn{2}{|c|}{$95 \%$ CI of Odds Ratio } \\
\hline & & & & \\
\hline Year & 0.049 & 0.031 & 1.05 & 0.99 & 1.12 \\
\hline Date & -0.013 & 0.091 & 0.99 & 0.83 & 1.18 \\
\hline Elevation & 0.00034 & -0.0013 & 1.00 & 1.00 & 1.00 \\
\hline Topographic index & 0.012 & 0.0082 & 1.01 & 1.00 & 1.03 \\
\hline Disturbance to vegetation & -0.033 & 0.013 & 0.97 & 0.94 & 0.99 \\
\hline Well Density & -0.012 & 0.011 & 0.99 & 0.97 & 1.01 \\
\hline Observer & -0.37 & 0.11 & 0.69 & 0.55 & 0.86 \\
\hline $\mathbf{S}$ & -0.40 & 0.18 & 0.67 & 0.47 & 0.96 \\
\hline
\end{tabular}

\section{Modeling using landscape-level parameters}

Other studies have found that spatial scales greater than $100 \mathrm{~m}$ in radius are most informative when determining how grassland birds react to human influences (e.g., Wiens et al. 2008, Koper et al. 2009, but see Koiper and Schmiegelow 2006). Koper et al. (2009) found that Sprague's Pipits decreased in relative abundance in response to edge up to $900 \mathrm{~m}$ away. However, the Koper et al. (2009) analysis incorporated several landcover types, e.g., crop, roads, water, whereas our study took place strictly in native grassland, and edges created by trails and roads were accounted for within our models. Models of grassland bird occurrence have found habitat features up to $1200 \mathrm{~m}$ away can serve as good predictors (e.g., Renfrew and Ribic 2002, Cunningham and Johnson 2006), including linear features that may influence habitat use by birds in open country at scales up to 1 to $2 \mathrm{~km}$ (Gutzwiller and Barrow 2003, Benitez-Lopez et al. 2010).

The predictive performance of habitat models for grassland birds depends upon the variables chosen, the location of the study site, and when, in terms of both season and year, data are collected. We expected that because soil particle size is tied to moisture retention and thus to vegetation cover (as reviewed by Wiens et al. 2008), particle size would be strongly related to vegetation type and productivity, and would help explain occurrence of the three species. In fact, soil texture had no explanatory power. Other habitat features, such as elevation and topography, had some predictive value, but their performance was inconsistent among species. Overall, landscape variables proved of limited use, but given the success of other research using similar metrics (e.g., Wiens et al. 2008), this may be an artifact of the limited area and duration of our study, in addition to a lack of available reference areas that did not contain well sites. For example, our study area was half the size $\left(\sim 90 \mathrm{~km}^{2}\right)$ of that used by Wiens et al. $(2008 ; \sim 190$ $\mathrm{km}^{2}$ ) and this latter study spanned 6 years. Of particular note, the occurrence of Sprague's Pipit was not strongly linked to elevation or topography in our study. Wiens et al. (2008), in contrast, found that pipits were more likely to be found at flatter locations than on steep hillsides.

In agreement with previous studies (Government of Canada 2008), our work documented an inverse 
Fig. 2. Likelihood of occurrence of Sprague's Pipit (Anthus spragueii) at a point count location on CFB Suffield (solid line; 95\% confidence intervals: dashed lines) predicted by total disturbance to natural vegetation caused by natural gas extraction (Table 5). The initial occurrence is based on the observation of Sprague's Pipit at 50.2\% at 544 point count locations in 2007 and 2008.

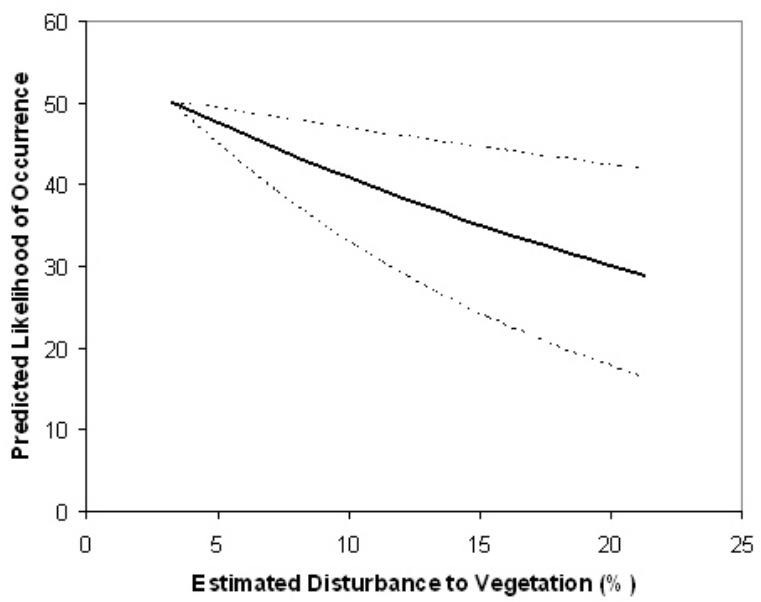

relationship between pipit occurrence and the proportion of habitat disturbed by humans, mainly in the form of industrial development. In Alberta and Saskatchewan prairie, Sprague's Pipit avoids small patches of grassland preferring larger patches (Davis 2004, Davis et al. 2006), avoids roads (Sutter et al. 2000, Koper and Schmiegelow 2006), and appears to avoid non-native grass species, like crested wheatgrass (Agropyron cristatum; Sutter 1997, Robbins and Dale 1999, Davis 2005, but see Davis et al. 1999). Crested wheatgrass is known to be associated with sites affected by natural gas extraction on CFB Suffield (B. Smith, unpublished manuscript).

Lack of predictive power of our models for two of the study species might have resulted from the small number of variables used in the study or the lack of sufficient variation within our parameters. In addition, sites were selected based on previous surveys and represented areas known to contain the three study species, thus the areas where they were most likely to be absent were never visited.

Models for breeding birds often focus on the quantity, shape, and edge of grassland available within a fragmented matrix (e.g., Winter and
Faaborg 1999, Davis 2004, Renfrew et al. 2005, Hamer et al. 2006). Direct measures of habitat quality such as local vegetation characteristics and distance to nearest edge are less common (Koper and Schmiegelow 2006). Our study took place in a large area composed entirely of grassland. Instead of demonstrating if birds avoid dramatic disturbances, such as forested edges or changes from native grasslands to crop fields, we found that even relatively small-scale human-caused disturbances within grassland can affect patterns of occupancy of one declined species, Sprague's Pipit, but not Chestnut-collared Longspur, which is also recognized as a species at risk. No areas of native grassland existed nearby that were free from human disturbance caused by oil and gas exploration and this may have masked effects caused by the simple presence of wells and accompanying disturbances.

In terms of understanding long-term viability of bird populations in the face of disturbance, we focused on occurrence and did not explore productivity, which has been shown in other studies of groundnesting birds near trails (Miller et al. 1998, Barton and Holmes 2007). We did not explore underlying mechanisms by which human disturbance might affect populations. These could involve changes in 
Table 6. Summary of the best mixed model logistic regression for describing presence-absence of Savannah Sparrows (Passerculus sandwichensis) on 544 points on CFB Suffield from 2007 and 2008 using a $100 \mathrm{~m}$ radius surrounding a point count location using treatment contrasts. Bolded parameters indicate odds ratios that differ from one.

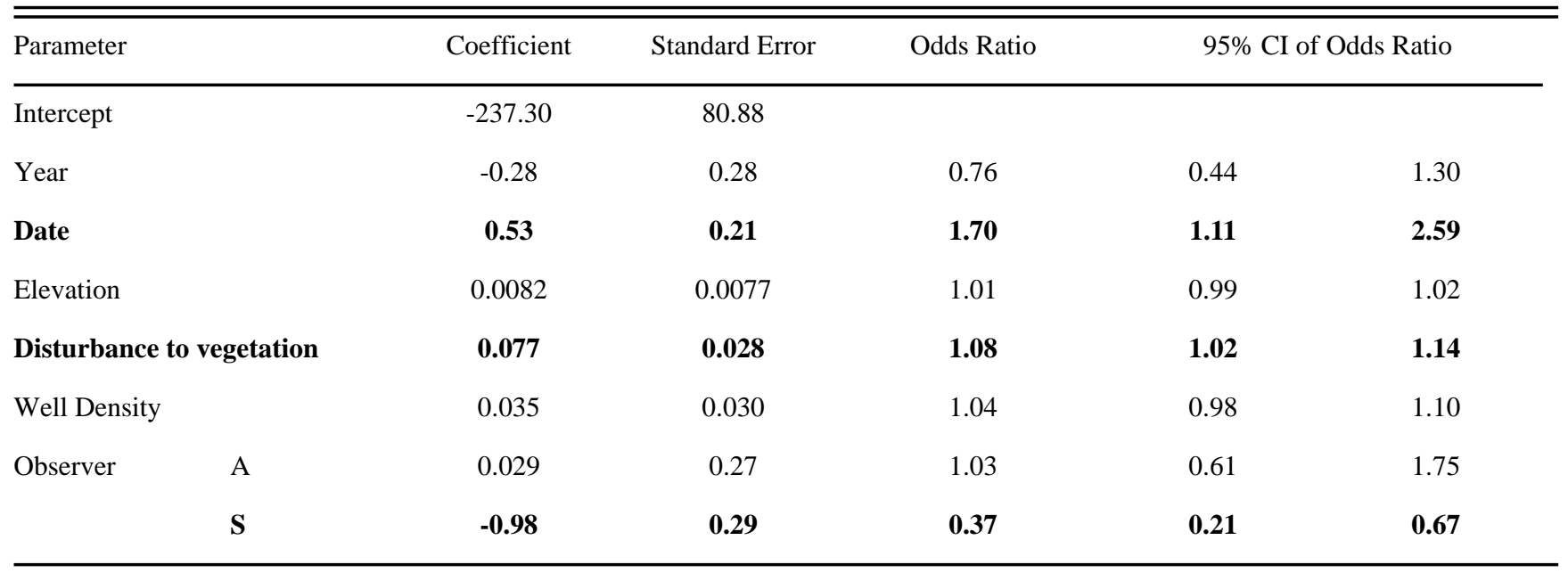

vegetation structure caused by invasive non-native plants and resultant changes in territory placement, invertebrate availability, and nesting success (Miller et al.1998, Barton and Holmes 2007, Hamilton 2010).

\section{CONCLUSION}

Our use of landscape metrics available from government agencies on the prairie, e.g., soil types and topography, showed some success in predicting the occurrence of Savannah Sparrow and Sprague's Pipit in the mixed-grass prairie of CFB Suffield. These metrics likely require greater levels of resolution and sensitivity to predict distribution of these species and other grassland birds reliably enough for use in conservation planning. We found that areas associated with human activities were more likely to be used by Savannah Sparrows, but less likely to be used by Sprague's Pipits compared with less disturbed areas. Thus, initial predictions for two of our three study species, Savannah Sparrow and Sprague's Pipit, were supported. Our results reflected the preference of Savannah Sparrows for taller vegetation and disturbed habitat and the avoidance of human disturbance by Sprague's Pipit. Chestnut-collared Longspur occurrence was not affected by well density, which likely reflects their ubiquity in the study area and moderate tolerance of disturbance. Disturbances, including well sites, pipelines, junctions, and offroad vehicle trails, cover only a small proportion $(3.25 \%)$ of the total surface area of our study site on CFB Suffield. The measurable response displayed by Savannah Sparrow and Sprague's Pipit is disproportionate given the small surface area that is directly disrupted.

Further increases in the area of native prairie disturbed by human activity on the small number of relatively intact prairie sites in western Canada, such as CFB Suffield, may cause a continued increase in widespread, generalized species of grassland birds and a reduction in the abundance of more specialized species of conservation concern. Whereas large scale studies, such as ours, may detect overarching distributional trends and coarse habitat preferences, smaller scale measurements of vegetation structure and composition are likely more tightly coupled to avian population responses and are still required to describe and understand 
Table 7. Summary of the best mixed model logistic regression for describing presence-absence of Chestnutcollared Longspurs (Calcarius ornatus) on 544 points on CFB Suffield from 2007 and 2008 using a 100 $\mathrm{m}$ radius surrounding a point count location using treatment contrasts. Bolded parameters indicate odds ratios that differ from one.

\begin{tabular}{|c|c|c|c|c|c|c|}
\hline \multirow{2}{*}{$\frac{\text { Parameter }}{\text { Intercept }}$} & & \multirow{2}{*}{$\begin{array}{c}\text { Coefficient } \\
529.30\end{array}$} & \multirow{2}{*}{$\begin{array}{c}\text { Standard Error } \\
99.84\end{array}$} & \multirow[t]{2}{*}{ Odds Ratio } & \multicolumn{2}{|c|}{$95 \%$ CI of Odds Ratio } \\
\hline & & & & & & \\
\hline Date & & -0.65 & 0.29 & 0.52 & $\mathbf{0 . 3 0}$ & 0.92 \\
\hline Elevation & & 0.024 & 0.0083 & 1.02 & 1.01 & 1.04 \\
\hline Topograp & & -0.53 & 0.10 & 0.59 & 0.48 & 0.72 \\
\hline \multirow[t]{2}{*}{ Observer } & $\mathbf{A}$ & 1.64 & 0.37 & 5.15 & 2.48 & 10.68 \\
\hline & $\mathrm{S}$ & 0.00088 & 0.27 & 0.54 & 0.59 & 1.71 \\
\hline
\end{tabular}

changes caused by the energy sector and other industrial activity.

Responses to this article can be read online at: http://www.ace-eco.org/vol6/iss 1/art7/responses/

\section{Acknowledgments:}

This study was made possible through financial support provided by the Department of National Defense, Alberta Conservation Association, Biodiversity Grant, and the Alberta Sports, Recreation Parks and Wildlife Fund. Thanks go out to Sara Majeski and Anna Wehrfritz-Hanson for help in the field. For help with analysis, thanks are due to Charlene Nielsen and Trevor Wiens. We would like to thank Canadian Forces Base Suffield for the access to the study site.

\section{LITERATURE CITED}

Adams, B. W., L. Poulin-Klein, D. Moisery, and R. McNeil. 2004. Rangeland plant communities and range health assessment guidelines for the dry mixedgrass natural subregion of Alberta.
Publication No. T/040. Rangeland Management Branch, Public Lands Division, Alberta Sustainable Resource Development, Lethbridge, Alberta, Canada.

Alberta Soil Information Center. 2001. Agrasid30: agricultural region of Alberta soil inventory database (Version 3.0). J. A. Brierley, T. C. Martin, and D. J. Spiess, editors. Agriculture and Agri-Food Canada, Research Branch. Alberta Agriculture, Food and Rural Development, Conservation and Development Branch, Edmonton, Alberta, Canada.

Ashenhurst, A. R., and S. J. Hannon. 2008. Effects of seismic lines on the abundance of breeding birds in the Kendall Island Bird Sanctuary, Northwest Territories, Canada. Arctic 61:190-198.

Askins, R. A., F. Chávez-Ramírez, B. C. Dale, C. A. Haas, J. R. Herkert, F. L. Knopf, and P. D. Vickery. 2007. Conservation of grassland birds in North America: understanding ecological process in different regions. Ornithological Monographs No. 64. American Ornithologists' Union, Washington, D.C., USA.

Barton, D. C., and A. L. Holmes. 2007. Off-highway vehicle trail impacts on breeding songbirds in Northeastern California. Journal of Wildlife Management 71:1617-1620. http://dx.doi.org/10.21 93/2006-026 
Benitez-Lopez, A., R. Alkemade, and P. A. Verweij. 2010. The impacts of roads and other infrastructure on mammal and bird populations: a meta-analysis. Biological Conservation 143:1307-1316. http://dx. doi.org/10.1016/j.biocon.2010.02.009

Brennan, L. A., and W. P. Kuvlesky, Jr. 2005. North American grassland birds: an unfolding conservation crisis? Journal of Wildlife Management 69:1-13. http://dx.doi.org/10.2193/0022-541X(2005)069<0001: NAGBAU> 2.0.CO;2

Burnham, K. P., and D. R. Anderson. 2002. Model selection and multimodel inference. SpringerVerlag, New York, New York, USA.

Canadian Environmental Assessment Registry (CEAR). 2007. Environmental impact statement for the EnCana shallow gas infill development in the CFB Suffield National Wildlife Area. CEAR Reference No. 05-07-15620. Canadian Environmental Assessment Agency, Ottawa, Ontario, Canada.

Cunningham, M. A., and D. H. Johnson. 2006. Proximate and landscape factors influence grassland bird distributions. Ecological Applications 16:1062-1075. http://dx.doi.org/10.1890/1051-0761 (2006)016[1062:PALFIG]2.0.CO;2

Dale, B. C. 1983. Habitat relationships of seven species of passerine birds at Last Mountain Lake, Saskatchewan. Thesis, University of Regina, Regina, Saskatchewan, Canada.

Dale, B. C., T. S. Wiens, and L. E. Hamilton. 2009. Abundance of three grassland songbirds in an area of natural gas infill drilling in Alberta, Canada. Pages 194-204 in Proceedings of the Fourth International Partners in Flight Conference: Tundra to Tropic. Partners in Flight. [online] URL: http://www.partnersinflight.org/pubs/McAllenProc/ articles/PIF09 Anthropogenic\%2 0Impacts/Dale PIF09. pdf.

Davis, S. K. 2004. Area sensitivity in grassland passerines: effects of patch size, patch shape, and vegetation structure on bird abundance and occurrence in southern Saskatchewan. Auk 121:1130-1145. doi:10.1642/0004-8038(2004)121[ 1130:ASIGPE]2.0.CO;2
Davis, S. K. 2005. Nest-site selection patterns and the influence of vegetation on nest survival of mixed-grass prairie passerines. Condor 107:605-616. http://dx.doi.org/10.1650/0010-5422(2005)107[0605: NSPATI]2.0.CO;2

Davis, S. K., R. M. Brigham, T. L. Shaffer, and P. C. James. 2006. Mixed-grass prairie passerines exhibit weak and variable responses to patch size. Auk 123:807-821. http://dx.doi.org/10.1642/0004-8038 (2006)123[807:MPPEWA]2.0.CO;2

Davis, S. K., D. C. Duncan, and M. Skeel. 1999. Distribution and habitat associations of three endemic grassland songbirds in southern Saskatchewan. Wilson Bulletin 111:389-396.

Dickson, T. L., B. J. Wilsey, R. R. Busby, and D. L. Gebhart. 2008. Grassland plant composition alters vehicular disturbance effects in Kansas, USA. Environmental Management 41:676-684. http://dx. doi.org/10.1007/s00267-007-9064-4

Fielding, A. H., and J. F. Bell. 1997. A review of methods for the assessment of prediction errors in conservation presence/absence models. Environmental Conservation 24:38-49. http://dx.doi.org/10.1017/S 0376892997000088

Forman R. T. T., B. Reineking, and A. M. Hersperger. 2002. Road traffic and nearby grassland bird patterns in a suburbanizing landscape. Environmental Management 29:782-800. "http://dx. doi.org/10.1007/s00267-001-0065-4

Government of Canada. 2008. EnCana shallow gas infill development project - Canadian Environmental Assessment Registry No. 05-05-15620. Canadian Environmental Assessment Agency, Ottawa, Ontario, Canada. [online] URL: http://www.ceaa.gc. ca/050/documents/25482/25482E.pdf.

Gutzwiller, K. J., and W. C. Barrow, Jr. 2003. Influences of roads and development on bird communities in protected Chihuahuan Desert landscapes. Biological Conservation 113:225-237. http://dx.doi.org/10.1016/S0006-3207(02)00361-0 
Hamilton, L. E. 2010. Effects of natural gas development on three grassland bird species in CFB Suffield, Alberta, Canada. Thesis, University of Alberta, Edmonton, Alberta, Canada.

Hamer, T. L., C. H. Flather, and B. R. Noon. 2006. Factors associated with grassland bird species richness: the relative roles of grassland area, landscape structure, and prey. Landscape Ecology 21:569-583. http://dx.doi.org/10.1007/s10980-005$\underline{2167-5}$

Hill, D.P., and L. K. Gould. 1997. Chestnut-collared Longspur (Calcarius ornatus). In A. Poole, editor. The birds of North America online. Number 288. Cornell Lab of Ornithology, Ithaca, New York, USA. [online] URL: http://bna.birds.cornell.edu/bna/ species/288.

Ingelfinger, F., and S. Anderson. 2004. Passerine response to roads associated with natural gas extraction in a sagebrush steppe habitat. Western North American Naturalist 64:385-395.

Koper, N., and F. K. A. Schmiegelow. 2006. A multi-scaled analysis of avian response to habitat amount and fragmentation in the Canadian dry mixedgrass prairie. Landscape Ecology 21:1045-1059. http://dx.doi.org/10.1007/s10980-006-0004-0

Koper, N., D. J. Walker, and J. Champagne. 2009. Nonlinear effects of distance to habitat edge on Sprague's pipits in southern Alberta, Canada. Landscape Ecology 24:1287-1297. http://dx.doi.org /10.1007/s10980-009-9375-3

Larson, D. L., P. J. Anderson, and W. Newton. 2001. Alien plant invasion in mixed-grass prairie: Effects of vegetation type and anthropogenic disturbance. Ecological Applications 11:128-141. http://dx.doi.o rg/10.1890/1051-0761(2001)011[0128:APIIMG]2.0. $\underline{\mathrm{CO} ; 2}$

McMaster, D. G., and S. K. Davis. 2001. An evaluation of Canada's Permanent Cover Program: habitat for grassland birds? Journal of Field Ornithology 72:195-325.

Miller, S. G., R. L. Knight, and C. K. Miller. 1998. Influence of recreational trails on breeding bird communities. Ecological Applications 8:162-169. http://dx.doi.org/10.1890/1051-0761(1998)008[0162: IORTOB]2.0.CO;2
Natural Resources Canada. 2004. GeoBase Canadian Digital Elevation Data. USGS DEM format. [online] URL: http://www.geobase.ca.

Reijnen, R., R. Foppen, and H. Meeuwsen. 1996. The effects of traffic on the density of breeding birds in Dutch agricultural grasslands. Biological Conservation 75:255-260.http://dx.doi.org/10.1016 /0006-3207(95)00074-7

Renfrew, R. B., and C. A. Ribic. 2002. Influence of topography on density of grassland passerines in pastures. American Midland Naturalist 147:315-325. http://dx.doi.org/10.1674/0003-0031(2002)147[0315: IOTODO]2.0.CO;2

Renfrew, R. B., C. A. Ribic, and J. L. Nack. 2005. Edge avoidance by nesting grassland birds: a futile strategy in a fragmented landscape. Auk 122:628-636. doi:10.1642/0004-8038(2005)122[0618: EABNGB]2.0.CO;2

Robbins, M. B., and B. C. Dale. 1999. Sprague's Pipit (Anthus spragueii). In A. Poole, editor. The birds of North America online. Number 439. Cornell Lab of Ornithology, Ithaca, New York, USA. [online] URL: http://bna.birds.cornell.edu/bna/spec ies/439.

Samson, F. B., F. L. Knopf, and W. R. Ostlie. 2004. Great Plains ecosystems: past, present and future. Wildlife Society Bulletin 32:6-15. http://dx.doi.org/ 10.2193/0091-7648(2004)32[6:GPEPPA]2.0.CO;2

Schielzeth, H. 2010. Simple means to improve the interpretability of regression coefficients. Methods in Ecology and Evolution 1:103-113. doi:10.1111/j .2041-210X.2010.00012.X

Sutter, G. C. 1997. Nest-site selection and nestentrance orientation in Sprague's pipit. Wilson Bulletin 109:462-469.

Sutter, G. C., S. K. Davis, and D. C. Duncan. 2000. Grassland songbird abundance along roads and trails in southern Saskatchewan. Journal of Field Ornithology 71:110-116.

Trombulak, S. C., and C. A. Frissell. 2000. Review of ecological effects of roads on terrestrial and aquatic communities. Conservation Biology 
14:18-30. http://dx.doi.org/10.1046/j.1523-1739.20 00.99084.X

Venier, L. A., J. Pearce, J. E. McKee, D. W. McKenney, and G. J. Niemi. 2004. Climate and satellite-derived land cover for predicting breeding bird distribution in the Great Lakes Basin. Journal of Biogeography 31:315-331. doi:10.1046/j.0305-0 270.2003.01014.x

von der Lippe, M., and I. Kowarik. 2007. Longdistance dispersal of plants by vehicles as a driver of plant invasions. Conservation Biology 21:986-996. http://dx.doi.org/10.1111/j.1523-1739 $.2007 .00722 . \mathrm{x}$

Wiens, J. 1969. An approach to the study of ecological relationships among grassland birds. Ornithological Monographs No. 8. American Ornithologists' Union, Washington, D.C., USA.

Wiens, T. S., B. C. Dale, M. S. Boyce, and G. P. Kershaw. 2008. Three way k-fold cross-validation of resource selection functions. Ecological Modelling 12:244-255. http://dx.doi.org/10.1016/j. ecolmodel.2007.10.005

Winter, M., and J. Faaborg. 1999. Patterns of area sensitivity in grassland-nesting birds. Conservation Biology 13:1424-1436. http://dx.doi.org/10.1046/j. 1523-1739.1999.98430.X

Winter, M., D. H. Johnson, and J. Faaborg. 2000. Evidence for edge effects on multiple levels in tallgrass prairie. Condor 102:256-266. http://dx.doi. org/10.1650/0010-5422(2000)102[0256:EFEEOM] 2.0.CO;2

Winter, M., D. H. Johnson, J. A. Shaffer, T. M. Donovan, and W. D. Svedarsky. 2006. Patch size and landscape effects on density and nesting success of grassland birds. The Journal of Wildlife Management 70:158-172. http://dx.doi.org/10.2193 /0022-541X(2006)70[158:PSALEO]2.0.CO;2 